Meta

Journal des traducteurs

Translators' Journal

\title{
Translation and Technical Communication: Chicken or Egg?
}

\section{Patricia Minacori et Lucy Veisblat}

Volume 55, numéro 4, décembre 2010

De la localisation à la délocalisation - le facteur local en traduction

From Localization to Delocalization - The Local Factor in Translation

URI : https://id.erudit.org/iderudit/045689ar

DOI : https://doi.org/10.7202/045689ar

Aller au sommaire du numéro

\section{Éditeur(s)}

Les Presses de l'Université de Montréal

\section{ISSN}

0026-0452 (imprimé)

1492-1421 (numérique)

Découvrir la revue

Citer cet article

Minacori, P. \& Veisblat, L. (2010). Translation and Technical Communication: Chicken or Egg? Meta, 55(4), 752-768. https://doi.org/10.7202/045689ar

\section{Résumé de l'article}

La traduction est une opération sur le sens : elle part d'un texte exprimé dans une langue pour arriver à un texte exprimé dans une autre langue. La communication technique implique, en revanche, de concevoir et de rédiger un document dans une langue, souvent à partir d'une compilation d'informations. La réponse à la question : « Laquelle, de la rédaction ou de la traduction, précède l'autre ? » semble assez évidente : les documents doivent être rédigés avant d'être traduits. Or, si l'on analyse la traduction et la communication technique aux États-Unis et en Europe, sous l'angle des formations et des métiers, la réponse à cette question n'est plus aussi tranchée. Aux États-Unis, les deux métiers requièrent des compétences différentes, notamment en ce qui concerne les langues, et les formations sont étanches. En Europe, et plus particulièrement en France, le métier de communicateur technique est bien plus récent et les formations sont souvent dispensées dans des départements de langues. Partant de ces constats, l'objectif de cet article est de plaider en faveur du lancement d'une enquête sur les compétences du communicateur technique, en se fondant sur la liste des compétences des traducteurs définies dans le programme de l'Union européenne " European Master's in Translation " (EMT). Elle permettra de voir quels sont les points de contact mais aussi les divergences par rapport aux compétences des traducteurs. L'objectif pourrait être de proposer un cadre de référence pour la formation des communicateurs techniques.
Ce document est protégé par la loi sur le droit d'auteur. L'utilisation des services d'Érudit (y compris la reproduction) est assujettie à sa politique d'utilisation que vous pouvez consulter en ligne.

https://apropos.erudit.org/fr/usagers/politique-dutilisation/ 


\title{
Translation and Technical Communication: Chicken or Egg?
}

\author{
PATRICIA MINACORI \\ Université Paris Diderot - Paris 7, Paris, France \\ patricia.minacori@eila.univ-paris-diderot.fr

\section{LUCY VEISBLAT} \\ Université Paris Diderot - Paris 7, Paris, France \\ lucy.veisblat@eila.univ-paris-diderot.fr
}

\section{RÉSUMÉ}

La traduction est une opération sur le sens: elle part d'un texte exprimé dans une langue pour arriver à un texte exprimé dans une autre langue. La communication technique implique, en revanche, de concevoir et de rédiger un document dans une langue, souvent à partir d'une compilation d'informations. La réponse à la question: «Laquelle, de la rédaction ou de la traduction, précède l'autre?» semble assez évidente: les documents doivent être rédigés avant d'être traduits. Or, si l'on analyse la traduction et la communication technique aux États-Unis et en Europe, sous l'angle des formations et des métiers, la réponse à cette question n'est plus aussi tranchée. Aux États-Unis, les deux métiers requièrent des compétences différentes, notamment en ce qui concerne les langues, et les formations sont étanches. En Europe, et plus particulièrement en France, le métier de communicateur technique est bien plus récent et les formations sont souvent dispensées dans des départements de langues. Partant de ces constats, l'objectif de cet article est de plaider en faveur du lancement d'une enquête sur les compétences du communicateur technique, en se fondant sur la liste des compétences des traducteurs définies dans le programme de l'Union européenne «European Master's in Translation» (EMT). Elle permettra de voir quels sont les points de contact mais aussi les divergences par rapport aux compétences des traducteurs. L'objectif pourrait être de proposer un cadre de référence pour la formation des communicateurs techniques.

\section{ABSTRACT}

Translation starts with a document in one language and ends with a document with the same meaning in another language. Technical communication entails designing and writing a document from scratch in one language. The answer to the question of "Which, of translation or writing, comes first?" seems relatively obvious - the document needs to be written before it can be translated. However, when looking at translation and technical communication as professions and examining how the professionals are trained, the answer is not quite as clear-cut. In the United States, translators and technical communicators have different qualifications, different skills - in particular different language skills - and have degrees in different fields. Only recently has there appeared a certain convergence between the professions. In Europe, and more specifically in France, the profession of technical communicator is quite recent, as are the corresponding academic programs. Many technical communicators came to the profession from translation. The convergence therefore is perceived as being far greater. The purpose of this paper is to launch a comparative study of the competences or skills of translators and technical communicators, based on the existing European Master's in Translation (EMT) list of competences for translators. The goal of this study would be to define the core skills for technical communicators, to examine to what extent they overlap with the competences of translators and ultimately, to establish a referential for training programs in technical communication. 


\section{MOTS-CLÉS/KEYWORDS}

communication technique, traduction, compétences, enquête, convergence technical communication, translation, skills, survey, convergence

\section{Introduction}

Translation is an operation that has existed as far back as we know. The same is most likely true for technical communication. As soon as mankind had a need to exchange, in order to construct ships, erect buildings, establish commercial operations, written communication found its natural place, even though in forms very different from those we know today.

Because translation was known in France before technical communication, and because of the way training in technical communication has developed, it is sometimes said, in that country, that technical communication stems from translation. Yet a document has to be written before it can be translated. It therefore remains to be seen which really came first, of the chicken or the egg.

We have decided to address this question from the angle of competences. Indeed, the goal of this analysis is to look for answers to the following:

- What competences are required of a technical communicator?

- What is the minimum set of those competences?

- Are they different from translators' competences, and if so, in what way?

We will start with a brief description of the two professions, emphasising the differences in the United States and in Europe. Indeed technical communication appeared far earlier in the United States, whereas the requirements became apparent in Europe at a later stage. In the same way the approach to academic programs differs from one continent to another. The North American writing programs are usually seated in English or engineering departments, clearly separated from the translation programs that belong to language departments. In Europe however both writing and translation programs tend to be located within language departments. Some experts recommend a convergence between the two professions and therefore between academic programs, and we will show this convergence already exists, particularly in France, where technical communication is often seen as one of the applications of languages.

We have started to analyse the document published by the European Union Directorate General for Translation, and to compare the listed minimum competences required of translators as part of the European Master's in Translation (EMT) program with those of technical communicators.

\section{Technical Translation and Technical Communication - Descriptions}

Based on observation of technical translation and technical communication professions, we would like to propose the following descriptions as a minimal common reference for this article: translation starts with a document in one language and ends with a document with the same meaning in another language; technical writing entails designing and writing a document from scratch, in one language.

These descriptions immediately highlight some common ground - communication for a special purpose is the main objective of both professions - and some different elements - several languages or a single language come into play. 


\subsection{Translation Paradigms}

From a minimal practical or a theoretical analysis, translation can be seen according to multiple perspectives since the same word is used both for the act and for the final product.

Diachronically, translation can be placed under certain paradigms. Kuhn (1963/1983) described a paradigm as a collection of beliefs, shared by scientists, about how problems should be understood. A revolution may happen, leaving ground to a new paradigm. But paradigm wars can also happen, leading back to the former paradigm or paving the way for a new one. If we consider the history of translation in our Western world (Ballard 2007), a movement can be seen between, for example:

- A paradigm of word-to-word to be faithful to God's words, acknowledged in first translations of the Bible;

- A creation paradigm in particular in Cicero's treaty "De Oratore" on translation to ban word-to-word and use the best expressions in Latin to respect the orators' eloquence;

- A sense paradigm put in place in the new Latin version (385 and $420 \mathrm{AD}$ ) of the Bible by Saint Hieronymus in which sense for sense is chosen;

- A text intention paradigm with Etienne Dolet and his five translation rules (1540) also banning word-to-word and wanting to express the author's intention;

- A creation paradigm with the so-called French movement "les Belles Infidèles" ("Unfaithful Beauties"), initiated by Nicolas Perrot d'Ablancourt and in which antiliteralism is advocated;

- A paradigm of fidelity to the source text during the Romantic period (Ballard 1999)

- A decision paradigm attributed to Levy (1967/2000) and proposing to talk about pragmatic translation.

The above paradigms can also be seen as a pendulum movement in three directions: in the first the author is magnified, in the second, the recipient is in the forefront, and in the third, translation becomes a creative work, in complete disconnection from the other two directions.

According to some experts, translation is also a moving object.

La traduction s'est émancipée depuis les trente dernières années, gagnant de l'assurance et délaissant peu à peu le dispositif scientifique de la linguistique, afin de tisser des liens d'interdisciplinarité avec diverses sciences humaines. (Boulanger, 2004: 58)

In the last thirty years, translation grew emancipated, gaining self assurance, leaving day after day the linguistics' scientific sphere and paving the way to inter-disciplinarity with other humanities (Our translation).

Technical communication ranks high amongst the humanities with strong interdisciplinary links with translation.

\subsection{A Brief History of Technical Communication}

Although one can trace technical writing as far back as Egyptian or Roman Antiquity, it is more common to refer to the period immediately following World War II as the birth date of modern technical communication.

As stated by O'Hara (2001) “Technical Writer” appeared as a job title at that time, as technology became more complicated and required standardised procedures and 
descriptions. There was, in particular, a need for proposal and technical writers who understood and knew how to write according to specifications issued by the military (mil specs).

The invention of the transistor in 1947 by William Shockley, John Bardeen, and Walter Brattain opened a new area leading, in its best-known application of the printed circuit, to the computer and generating a need for new genres in technical communication, such as user manuals or installation manuals, to name only a few.

The ensuing wave of technological developments, not only in the computer industry but also in other areas such as the aeronautical, automobile or consumer goods industry, led to a considerable increase in the number of technical writers, who soon found the need to gather within associations to promote and defend their profession.

This led in 1953 to the establishment of two organisations concerned with improving the practice of technical writing: the Society of Technical Writers and the Association of Technical Writers and Editors. In 1957, these merged to form the Society of Technical Writers and Editors, a predecessor of the current Society for Technical Communication (STC). In our article, we will follow this diachronic shift, and opt for the more contemporary terms of technical communicator and technical communication.

Fifty years later, the profession has taken on many different forms and denominations. New tools - from typewriters to word processors to desktop publishing, from standard mark up languages to HTML and XML editors - and new publishing media - electronic publishing, web-based documentation, e-learning platforms - have generated over time a varied number of denominations for technical writers; technical communicator, copywriter, user information engineer, learning product engineer, editorial webmaster, information architect, and in the past year, content strategist are only a few examples.

One of the more recent trends in the global economy is the outsourcing of technical writing to emerging countries where English is considered to be a second mother tongue to a large majority of the population. India is an obvious example, where English is the most commonly spoken language after Hindi and the most read and written language in the country. With regard to the history of technical communication in the western world, this entails a shift in the skills of technical communicators, from design and writing skills to project management and editing skills.

The above evolutions in tools, skills, denominations and media can be construed as observations of the kinetics of technical communication. One should add to these another major kinetic aspect, which is the expansion of technical communication throughout the world, as testified by the emergence of "out-of-the USA" chapters of the STC and the creation of worldwide organisations such as Intecom or TC Europe, the umbrella organisation for many national organisations, such as:

- TEKOM in Germany (established as early as 1978)

- ISTC in the UK

- CSVTK in the Czech Republic

- CRT in France

- COM\&TEK in Italy

- FTI in Sweden

- TECOM Schweiz in Switzerland 
- STIC in the Netherlands

- STVY in Sweden

- APCOMTEC in Portugal.

One constant observation throughout the half-century of existence of technical communication, however, is that despite a growing internationalisation of the profession, English remains the most frequently used language worldwide for technical communication, and, bar a few exceptions, the only language used in the field in the USA.

This last observation is paramount in the differentiation we claim to emphasise between technical translation and technical communication.

\section{Translation and Technical Communication in Europe}

In Europe, the two professions share neither the same history nor the same development. Each in its own way, however, has become a part of the spectrum of the need for user information.

\subsection{The Need for Translation in Europe}

A parallel can be drawn between the emergence of international organisations and the establishment of translation schools. The League of Nations established its headquarters in Geneva in 1929 and the Ecole de Traduction et d'Interprétation (ETI) opened in 1941 in that very same city. The treaty creating the European Coal and Steel Community came into force in 1958 and new schools of translation emerged, highly encouraged and stimulated by the first European statement defining the official languages, also adopted in 1958: Dutch, French, German and Italian. Three of these major schools of translation were created around the same time: the Ecole Supérieure de Traduction et d'Interprétation (ESIT and the Institut Supérieur d'Interprétation et de Traduction (ISIT) in 1957, both in Paris, France; and the Institut Supérieur de Traduction et d'Interprétation (ISTI) in 1958 in Brussels, Belgium (Froeliger, to be published).

Another impetus was given to translation by the Treaty on European Union providing free circulation of capital, goods, services and people (1992). Four major universities in France anticipated the consequences of the Treaty on the volume of documentation to be translated: Paris Diderot-Paris 7 (1990), Rennes II (1990), Strasburg and Grenoble II (1992).

The unification of degrees in Europe was also reached through a process stemming from the Bologna Declaration in 1999. The first aim of the process was to structure higher education into three cycles (Bachelor, Master and Doctorate) to enable mobility within Europe and to give European diplomas a major visibility.

Over the past ten years, the French Ministry of Education has been emphasising the need to professionalise the curricula and better prepare students to embrace a career. Many language departments saw translation degrees as the most obvious road to professionalisation in their domain, this leading to the creation of as many as 46 different translation degrees within five years. The situation is plethoric and not good for the profession. Few of these new degrees meet the criteria set by the European Union (EU) and the General Directorate for Translation in their European 
Master's in Translation (EMT) Program.

The number of highly qualified translators is set to expand in the EU, in particular following the latest enlargements of 2004 and 2007, bringing the total number of member countries up to 27 and the number of languages to 23. The problem for the Organisation is now to hire competent translators in as many as 231 language pairs - based on the use of pivot languages - and to replace the professionals due to retire in the years to come. The EMT label is granted for four years by the EU to universities in Europe training translators to high professional standards. The Directorate General for Translation organised conferences to explain the challenge. The candidates were asked to answer a call to enter the EMT program and, in 2009, 34 European programs of which seven only in France, including Paris Diderot, were selected and received membership for four years.

The list of competences will be highly interesting to consider, when we come to comparing the skills in the technical translation and technical communication professions.

\subsection{Technical Communication in France Today - A Recent Profession}

In France, and indeed in most European countries, technical communication, as a skill and a profession, emerged as late as the mid-eighties or early nineties, that is almost 50 years after the first recognition in the USA and much later than technical translation.

In France, two associations, STC France (1991) and the Conseil des Rédacteurs Techniques, CRT (1992) were created by professionals who saw the need to gather forces, make their profession known and market their skills.

It has only been in the past ten years or so that companies have been specifically looking to hire technical communicators, when confronted with the demand for user-friendly documentation and with the quality and usability of product documentation appearing as criteria in the overall assessment of a product.

The lack of positions defined as technical communicators in the industry was probably also linked to the lack of degrees preparing for the profession. We venture that one of the reasons for this may be the emphasis the French education system (rightly) puts on writing skills at all levels of education and in all disciplines. Combined with the system of the Grandes Ecoles (excellence engineering or administration schools) from which many company and department managers graduated, it is an engrained acceptance that the engineers know how to write and only the engineers have the technical knowledge necessary to explain the complexity of their products to users. We of course know that is not the case, and that despite their good writing skills, most albeit excellent engineers do not have the pedagogical skills or the ability to look at things from the user's point of view, unless they have been specifically trained.

The technical communication programs in France can be classified under two categories:

- those programs in translation, communication, multimedia development that include technical writing modules;

- specific degrees in Technical Writing (UTC Compiègne, Limoges, Clermont-Ferrand, Paris Diderot-Paris 7). 


\subsection{Links between Translation and Technical Communication at Paris Diderot}

At Paris Diderot, a translation program was created in 1990. It was then called "DESS Industrie de la langue et traduction spécialisée (ILTS)," DESS standing for "Diplôme d'études supérieures spécialisées." It became a Master's degree with the Bologna Process.

From the very beginning, the program was constructed upon the apprenticeship system, put in place by the French Government to tackle a high unemployment rate among young people. The Paris Diderot translation program was a pioneer in France at that level of education. This foresight was due to the visionary understanding of one woman, Claudie Juilliard, whose pro-activity has contributed to match the demands of companies and the training offer in the Applied Languages Department.

In 1999, the DESS ILTS was followed by the RTMI Technical writing program, later to become CDMM (Conception de documentation multilingue multimédia). The approach was interesting at several levels:

- The program was set up in an Applied Languages department, showing a shift of the emphasis from technical expertise to language expertise;

- The demand for trained technical writers came from the companies themselves, who were up to then requesting translation students from the ILTS program to perform writing tasks;

- The contents of the program were closely defined with the companies and future employers of the students.

The two programs ILTS and CDMM were intended to:

- Satisfy a demand from companies, first in translation then in technical writing;

- Offer the students good job opportunities, with statistics showing a high rate of employability (up to $100 \% 3$ to 6 months after graduation);

- Create a convergence between the translation and the technical writing programs, using the feedback engrained from ten years of practice in the first to adapt it to the second, in particular in dealing with apprenticeship laws and rules;

- Launch research programs in the two sectors of translation and technical communication.

The closeness of the two programs and the history of the communication program would appear as an answer to the Chicken or Egg? question. We will show later on however that the answer is not quite as clear-cut as it may appear.

\section{Trends in Translation and Technical Communication}

As a result of a survey on translation and technical communication, Maylath, Gnecchi, et al. (2007) observed a growing convergence of the two professions in the industry in North America, perceived it as an added value, and suggested the need for a greater convergence in academic programs in those fields. A survey was also conducted in Europe and the results showed a similar convergence in the industry, something that was already recognised by academia in Europe, as made apparent by the emergence of technical communication programs in Applied Languages departments, in parallel to existing translation programs. 
In their article on convergence, the authors outlined that due to ratification of trade agreements like the North American Free Trade Agreements (NAFTA) in 1994, the creation of the World Trade Organisation (WTO) in 1995 after renegotiation of the GATT Treaty and the successive enlargements of the EU, international trade expanded greatly. As a consequence so did the volume of technical documentation linked to the traded products. That is why the demand for translation and technical communication sharply increased in the 90's.

We believe that two other elements combined to give great impetus to translation and technical communication: the growing concern over localisation of software in the mid 80's, and the generalisation of the World Wide Web in the 90's.

Growing worldwide access to product information created a requirement for that information to be made available in more than the one language it was initially written in - English in most cases. This introduced a wide debate on standardisation versus localisation and the importance of taking not only language but also cultural aspects into consideration.

According to Sing and Pereira (2005), advocates of standardisation reckon technology develops and is globally dispersed so cultural distance should be minimised, while others consider web sites should be customised to be adapted to end-users.

Sing and Pereira (2005) sampled web sites from different countries that were evaluated by 627 respondents, also from different countries. Attitude towards the web sites and purchase intentions were measured. The answers were strongly in favour of highly adapted web sites. Furthermore, according to the same authors, a Forrester research found that non-English speaking users stay connected twice as long on web sites localised into their own language as they did on English-only web sites.

The authors proposed a segmentation ranging from standardised web sites to culturally customised web sites and pointed out the greater benefits and success of culturally customised sites. That is to say, translation and localisation are not sufficient and sites have to be clearly targeted at a culturally specific audience.

The implication is that the tasks of the translator will go beyond translation and localisation, and require some re-writing of the original information. We see here an illustration of the convergence of skills between translators and technical communicators.

In the field of technical communication, yet another trend is reflected in the new concepts and requirements emerging within the digital community. New job denominations such as "Information Architect" or "Content Strategist" are permeating the terminology to qualify experts dealing with creation of content for state-of-the-art web sites, generating traffic and purchases. In the model illustrated below (see Figure 1), content strategists appear in a central position with other experts linking in to them. 


\section{FIGURE 1}

\section{Collaboration with Content Strategist}

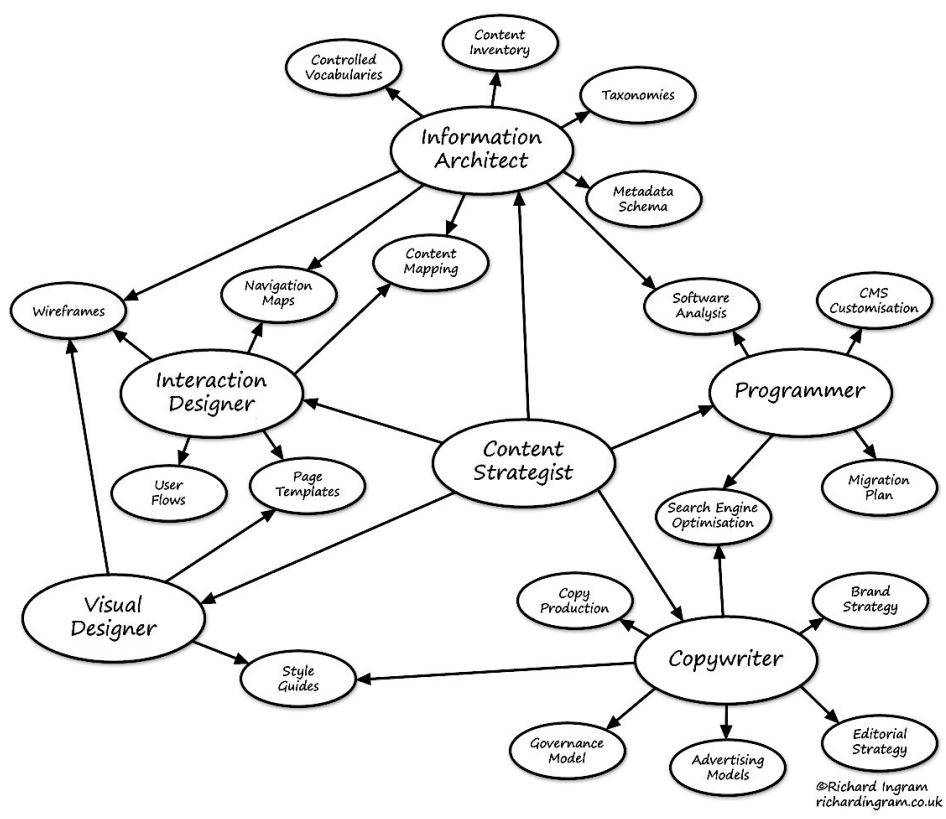

The above model, presented at the Content Strategy 2010 Forum organised in Paris on 15-16 April 2010 by the STC France Chapter, seems to represent a fundamental change in the way technical communicators present to users and customers the value of what they do.

It will be interesting to investigate and analyse how these new roles affect the convergence between translation and technical communication. Beyond that, and because, as pointed out by Maylath, Gnecchi, et al. (2007), professional visibility of technical communicators in Europe is low and the proliferation of different job titles brings on a greater confusion in the general public, we believe it would be useful to identify the set of common skills that qualify technical communicators, whatever their title.

\section{Current Research on Skills}

The question we want to address is what are the technical communicators' skills? Can common ground be found with translators' competences? What are the differences?

Three studies seem particularly relevant to our purpose: Maylath, Gnecchi, et al. (2007) as quoted earlier, Gouadec (2009) and the EMT list of translators' competences. Maylath's study examined the convergence between translators' and technical communicators' roles. Gouadec presented an exhaustive overview of the professions linked to languages, such as translation, interpretation or technical communication and proposed a list of competences, aptitudes and qualities. The EMT list appeared as closest to our concerns:

- It provides us with a validated list of translators' skills;

- The classification takes into account both academic training and professional experience; 
- The level of detail corresponds to our own objective of defining common European terms of reference;

- It will make it simpler to compare lists of skills built on a similar model.

The specific history of technical communication and technical translation academic programs in Paris Diderot demonstrates that both professions have a wide common ground in terms of skills. The very reason that the technical communication program was created at Paris Diderot was that a number of partner companies were using interns in the technical translation program to - successfully - perform technical writing skills.

We were able to determine which skills of the technical translation students were most attractive to their employers:

- ability to analyse and understand a technical text;

- ability to convey, in another language, the meaning of the original text;

- ability to grasp the technical level of the intended audience;

- ability to write clear and understandable instructions in the target language - those instructions often clearer and more understandable than in the source language.

We used this as a basis for identifying an initial list of common skills.

At the same time, however, those companies that were calling upon technical translators - or technical translation students - to perform technical communication tasks, were also requesting that these students be trained in a number of skills and tools that were distinct from those used in technical translation and specific to technical communication.

This helped us to define an initial list of skills specific to technical communication, and distinct from technical translation.

We also make the hypothesis that there exists, for each profession, a set of core skills - those without which one cannot adequately perform the tasks required of a professional - and non-core skills - those that enable the professionals to better perform their tasks, but are not essential.

The EMT list of competences was conceived as a set of the minimum competences for translators. Our purpose is not to question the EMT list but to research if and how core skills for translators and for technical communicators overlap in some areas.

\section{Analytical Approach to Technical Communication Skills}

We observe that very little research as been conducted in Europe on technical communication and more specifically, on skills applied in the field. Just as technical communication is a young profession, in France in particular, so is research in the field only emerging. The difficulty partly resides in the structure of national research authorities where no specific mention of technical communication appears, even in the "sections" to which it could be attached. This entails a lack of positions of professors or associate professors and, as a consequence, a lack of academic research.

We suggest that a basis for an analytical approach could be to start from the list of translators' competences as examined by the EU for the EMT program to outline the skills of technical communicators.

We have purposely been using the two terms competences and skills as synonyms. A choice of terminology needs to be made. 
The first question to be answered is the choice of the term "competence" as explained in the EU document "Competences for professional translators, experts in multilingual and multimedia communication" for the EMT program:

By "competence," we mean the combination of aptitudes, knowledge, behaviour and know-how necessary to carry out a given task under given conditions. This combination is recognised and legitimised by a responsible authority (institution, expert).

We notice however that in literature dealing with technical communication, the term skill is often preferred to that of competence. We also come across the terms aptitude, behaviour, knowledge or know-how (Winterton 2005) and we are therefore faced with having to make a choice for the purpose of this article. That choice is not an easy task. Amongst the definitions proposed by the Concise Oxford Dictionary (2005), we selected those that seemed the most relevant to our topic:

- Aptitude is the "ability or fitness, esp. to acquire a particular skill" (62)

- Behaviour is the "response (of a person, animal, etc) to a stimulus" (116)

- Skill means "expertness, practised ability, facility in an action" (1301)

- Competence (also competency) is "an area in which a person is competent; a skill" (271)

- Knowledge is "awareness or familiarity gained by experience, theoretical or practical understanding of a subject" (753)

- Know-how is a "practical knowledge; technique, expertise; natural skill or invention" (753).

If we consider these definitions, the differences between the terms do not clearly appear. We examined the definitions proposed by specialists of information society and found that they identified the difference between knowledge and skill as:

Knowledge may be seen as our understanding of how our everyday world is constituted and how it works. Skills involve the ability to pragmatically apply, consciously or even unconsciously, our knowledge in practical settings. In this setting, "skills" can be conceived as the technical aspects of competence, emphasizing the aspect of "how to do." (Anttiroiko, Lintilä et al. 2001: 29)

Going a step further, Virkus (2003) also considers synonyms of key skills. Core skills, transferable skills, transversal skills, generic skills, soft skills, personal skills, core competencies, key competencies, general competencies, soft competencies are used to describe the transferable skills which underpin competent performance in all fields.

For the sake of clarity and consistency, and because Anttiroiko's mention of skill as a technical competence we will now use the term skill, except for any reference to the EMT, where we will use their term of choice competence.

Going back to the list of competences published by the EU for the EMT program, six competences were proposed and 48 sub competences were listed under the six headings:

- Translation service provision

- Language

- Intercultural

- Information mining

- Technological

- Thematic 
The next question that requires exploring is to what extent the EMT competences are transferrable from translation to technical communication as such. What can be observed, in both the US and Europe, is an unquestionable need for the two professions to work closely together and to understand the implications of writing for translation. It is therefore generally accepted that academic programs in technical communication and technical translation should include courses in the other discipline, in order to create the best possible conditions for collaboration. It is through this comparison of skills in both fields that contents of courses will be successfully defined.

Our first approach was to use the EMT list to create an alpha version of a survey that we sent to only a small number (20) of technical communicators. We simply replaced "translation" by "technical communication" to elicit initial feedback. The answers were unanimous: the different entries were too vague and the general feeling was they were inappropriate to technical communication.

We have started to refine the list in order to adapt it to technical communication. The version provided in Appendix 1 is to be considered as work in progress. We introduced new categories of skills that are specific and important to technical communication, such as writing skills, information architecture and visual literacy, and new labels, as for example under technological skills. Preciseness being a fundamental quality of technical communicators, some of the entries provided in the EMT list should be rewritten to ensure there is no possible ambiguity. For example, the entry "Being aware of the social role of the translator" cannot translate simply to "Being aware of the social role of the technical communicator." It will need to be more specific and define whether it refers to the technical communicator's role in society or within an organisation.

Our analysis forms only the basis of potential research. Many pending questions remain to be answered, including questions of methodology.

\section{Conclusion}

The analysis of the two professions of translators and technical communicators, in the US and in Europe, shows somewhat opposite trends.

In the US, where there is an established history of technical communication in the industry, translation is not considered as an offspring of technical communication, if only because of the difference of requirements in language skills. In Europe, the opinion that technical communication is a form of translation is not uncommon, hence the initial question of "Chicken or Egg?" The effort to answer this brings up another question, that of "Which skills for technical communicators?" The time has come to analyse the convergence or overlap of skills between the professions, for purposes of comparison.

The approach not having been taken before, we hope the research could be a useful frame of reference in several fields, such as for establishing technical communication curricula - possibly leading to a label similar to the EMT label - providing a basis for professional certification or contributing to the evolution of recruitment criteria for technical communicators.

We formulate the hope that this research will also give indications on future trends in job descriptions and titles, linked to new business approaches (outsourcing) 
or requirements (content strategy, community management...), thus paving the way for further studies on technical communication, in France.

\section{REFERENCES}

Anttiroiko, Ari, Lintilä, Leena and Savolainen, Reijo (2001): Information Society Competencies of Managers: Conceptual Considerations. In: Erik PANZAR, Reijo SAVolaInEN and Païvi TrnjäLä, eds. In Search for a Human-centred Information Society. Tampere: Tampere University Press, 27-57.

Ballard, Michel (1999): Claude-Gaspar Bachet de Mériziac. Circuit. 65:20-21.

Ballard, Michel (2007): De Cicéron à Benjamin, Traducteurs, Traductions, Réflexions. Presses Universitaires du Septentrion: Villeneuve d'Ascq.

Boulanger, Pier-Pascale (2004): L'épistémologie cinétique de la traduction: catalyseur d'éthique. TTR. 17(2):57-66.

European Union. Competences for professional translators, experts in multilingual and multimedia communication. Visited 9 May 2010, <http://ec.europa.eu/dgs/translation/programs/emt/key_documents/emt_competences_translators_en.pdf $>$.

Froeliger, Nicolas (to be published): L'institutionnalisation au risque de la déstructuration: la question de la professionnalisation en traduction. In: Jose Carlos Hererras, ed. L'Europe des 27 et ses langues, minutes of the international conference L'Europe des 27 et ses langues. Paris: Université Paris Diderot, December 3-5, 2009.

GouAdec, Daniel (2009): Guide des métiers de la traduction - localisation et de la communication multilingue et multimedia. Paris: La Maison du Dictionnaire.

Kunn, Thomas (1963/1983): The Structure of Scientific Revolutions. Chicago: University of Chicago Press.

Levy, Jiri (1967/2000): Translation As A Decision Process. In: Laurence Venuti, ed. The Translation Studies Reader. London/New York, 148-159.

Maylath, Bruce, Gnecchi, Marusca, Mousten, Birthe, et al. (2007): Professional Communication and Translation in Convergence. In: IEEE International Professional Communication Conference Proceedings, Montreal, 14 July 2008. New York: IEEE, 191-205.

O'Hara, Frederick M., Jr. (2001): A Brief History of Technical Communication. STC's $48^{\text {th }}$ Annual Conference Proceedings, Society for Technical Communication, Arlington, Va., 500-504. Visited 9 May 2010, <http://www.stc.org/confproceed/2001/PDFs/STC48-000052. pdf $>$.

Sing, Nitish and Pereira, Arun (2005): The Culturally Customized Web Site: Customizing Web Sites for The Global Marketplace. Oxford: Elsevier Butterworth - Heinemann.

Thompson, Della (2005): The Concise Oxford Dictionary of Current English. Oxford: Clarendon Press.

Virkus, Sirje (2003): Information Literacy: Seeking Meaning, Competency, Skills and Literacy. Lecture at Humbold University. Visited 9 May 2010, <http://www.forum-benutzung.de/ pub/bscw.cgi/d14724/Information\%20Literacy\%20/\%20von\%20Sirje\%20Virkus>.

Winterton, Jonathan, Delamare - Le Deist, Françoise, Stringfellow, Emma. Typology of knowledge, Skills and Competences: Clarification of the Concept and Prototype, Center for European Research on Employment and Human Resources, Groupe ESC Toulouse, Research Report Elaborated on behalf of Cedefop/Thessaloniki (26 January 2005). Visited 9 May 2010, <http://www.ecotec.com/europeaninventory/publications/method/CEDEFOP_ typology.pdf $>$. 


\section{APPENDIX}

\section{Comparison of Translators' Competences and Technical Communicators' Skills}

\begin{tabular}{|c|c|}
\hline $\begin{array}{l}\text { EMT Categories of Competences for Translators } \\
\text { In "Competences for professional translators, } \\
\text { experts in multilingual and multimedia } \\
\text { communication" }\end{array}$ & $\begin{array}{l}\text { Suggested Categories of Skills for Techn } \\
\text { Communicators }\end{array}$ \\
\hline Translation Service Provision Competence & Technical Communicatio \\
\hline Interpersonal Dimension & Interpersonal Dimension \\
\hline $\begin{array}{l}\text { - Being aware of the social role of the translator } \\
\text { - Knowing how to follow market requirements } \\
\text { and job profiles (knowing how to remain aware of } \\
\text { developments in demand) } \\
\text { - Knowing how to organise approaches to clients/ } \\
\text { potential clients (marketing) } \\
\text { - Knowing how to negotiate with the client (to } \\
\text { define deadlines, tariffs/invoicing, working } \\
\text { conditions, access to information, contract, rights, } \\
\text { responsibilities, translation specifications, tender } \\
\text { specifications, etc.) } \\
\text { - Knowing how to clarify the requirements, } \\
\text { objectives and purposes of the client, recipients of } \\
\text { the translation and other stakeholders } \\
\text { - Knowing how to plan and manage one's time, } \\
\text { stress, work, budget and ongoing training } \\
\text { (upgrading various competences) } \\
\text { - Knowing how to specify and calculate the } \\
\text { services offered and their added value } \\
\text { - Knowing how to comply with instructions, } \\
\text { deadlines, commitments, interpersonal } \\
\text { competences, team organisation } \\
\text { - Knowing the standards applicable to the } \\
\text { provision of a translation service } \\
\text { - Knowing how to comply with professional ethics } \\
\text { - Knowing how to work under pressure and with } \\
\text { other experts, with a project head (capabilities for } \\
\text { making contacts, for cooperation and } \\
\text { collaboration), including in a multilingual } \\
\text { situation } \\
\text { - Knowing how to work in a team, including a } \\
\text { virtual team } \\
\text { - Knowing how to self-evaluate (questioning one's } \\
\text { habits; being open to innovations; being } \\
\text { concerned with quality; being ready to adapt to } \\
\text { new situations/conditions) and take responsibility }\end{array}$ & $\begin{array}{l}\text { - Being aware of the social role of the technical } \\
\text { communicator } \\
\text { - Knowing how to follow market requirements } \\
\text { and job profiles (knowing how to remain aware of } \\
\text { developments in demand) } \\
\text { - Knowing how to organise approaches to clients/ } \\
\text { potential clients (marketing) } \\
\text { - Knowing how to negotiate with the client (to } \\
\text { define deadlines, tariffs/invoicing, working } \\
\text { conditions, access to information, contract, rights, } \\
\text { responsibilities, technical writing specifications, } \\
\text { tender specifications, etc.) } \\
\text { - Knowing how to clarify the requirements, } \\
\text { objectives and purposes of the client, recipients of } \\
\text { the technical documentation and other } \\
\text { stakeholders } \\
\text { - Knowing how to plan and manage one's time, } \\
\text { stress, work, budget and ongoing training } \\
\text { (upgrading various skills) } \\
\text { - Knowing how to specify and calculate the } \\
\text { services offered and their added value } \\
\text { - Knowing how to comply with instructions, } \\
\text { deadlines, commitments, interpersonal skills, } \\
\text { team organisation } \\
\text { - Knowing the standards applicable to the } \\
\text { provision of a technical writing service } \\
\text { - Knowing how to comply with professional ethics } \\
\text { - Knowing how to work under pressure and with } \\
\text { other experts, with a project head (capabilities for } \\
\text { making contacts, for cooperation and } \\
\text { collaboration), including in a multilingual } \\
\text { situation } \\
\text { - Knowing how to work in a team, including a } \\
\text { virtual team } \\
\text { - Knowing how to self-evaluate (questioning one's } \\
\text { habits being open to innovations; being concerned } \\
\text { with quality; being ready to adapt to new } \\
\text { situations/conditions) and take responsibility }\end{array}$ \\
\hline
\end{tabular}




\begin{tabular}{|c|c|}
\hline Production Dimension & Publishing Skills \\
\hline $\begin{array}{l}\text { - Knowing how to create and offer a translation } \\
\text { appropriate to the client's request, i.e., to the aim/ } \\
\text { skopos and to the translation situation } \\
\text { - Knowing how to define stages and strategies for } \\
\text { the translation of a document } \\
\text { - Knowing how to define and evaluate translation } \\
\text { problems and find appropriate solutions } \\
\text { - Knowing how to justify one's translation choices } \\
\text { and decisions } \\
\text { - Mastering the appropriate metalanguage (to talk } \\
\text { about one's work, strategies and decisions) } \\
\text { - Knowing how to proofread and revise a } \\
\text { translation (mastering techniques and strategies } \\
\text { for proofreading and revision) } \\
\text { - Knowing how to establish and monitor quality } \\
\text { standards }\end{array}$ & $\begin{array}{l}\text { - Knowing how to create and offer a technical } \\
\text { document appropriate to the client's request, } \\
\text { - Knowing how to define stages and strategies for } \\
\text { a technical document } \\
\text { - Knowing how to define and evaluate problems } \\
\text { and find appropriate solutions for a technical } \\
\text { document } \\
\text { - Knowing how to justify one's technical writing } \\
\text { choices and decisions } \\
\text { - Mastering the appropriate metalanguage (to talk } \\
\text { about one's work, strategies and decisions) } \\
\text { - Knowing how to proofread and revise a } \\
\text { technical document (mastering techniques and } \\
\text { strategies for proofreading and revision) } \\
\text { - Knowing how to establish and monitor quality } \\
\text { standards (testing...) }\end{array}$ \\
\hline Language Competence & Writing Skills \\
\hline \multirow[t]{5}{*}{$\begin{array}{l}\text { - Knowing how to understand grammatical, } \\
\text { lexical and idiomatic structures as well as the } \\
\text { graphic and typographic conventions of language } \\
\text { A and one's other working languages (B, C) } \\
\text { - Knowing how to use these same structures and } \\
\text { conventions in A and B } \\
\text { - Developing sensitivity to changes in language } \\
\text { and developments in languages (useful for } \\
\text { exercising creativity) }\end{array}$} & $\begin{array}{l}\text { - Knowing how to write to technical writing } \\
\text { standards (simplicity, precision, conciseness, } \\
\text { consistency, etc.) } \\
\text { - Knowing how to adapt language to the reader/user } \\
\text { - Knowing how to adapt terminology to the } \\
\text { reader/user } \\
\text { - Knowing how to master plain language } \\
\text { - Knowing how to master controlled language } \\
\text { - Knowing how to write for a single sourcing } \\
\text { environment } \\
\text { - Mastering concepts and methodology for web } \\
\text { site content creation } \\
\text { - Mastering concepts and methodology for E- } \\
\text { learning modules }\end{array}$ \\
\hline & Information Architecture \\
\hline & $\begin{array}{l}\text { - Knowing how to understand requirements } \\
\text { (reading the existing documentation, interview } \\
\text { stakeholders and conduct a content inventory) } \\
\text { - Knowing how to define the macrostructure of a } \\
\text { document and its overall consistency (including } \\
\text { where it consists of visual and sound elements) } \\
\text { - Knowing how to organise content with } \\
\text { consistency, present information to convey } \\
\text { meaning. } \\
\text { - Knowing how to facilitate access to information } \\
\text { (intuitive navigation in a web site, or in any } \\
\text { document) }\end{array}$ \\
\hline & Visual Literacy \\
\hline & $\begin{array}{l}\text { - Knowing how to create or choose illustrations } \\
\text { that accurately convey the message (pictures, } \\
\text { screen captures, hand gestures, pictograms...) } \\
\text { - Knowing how to organise illustrations, how to } \\
\text { display them for maximum meaning, to catch the } \\
\text { reader's attention } \\
\text { - Knowing how to use graphic software packages } \\
\text { to work on photos or screen captures, to make } \\
\text { them more legible, to emphasise the important } \\
\text { points, to remove unimportant elements } \\
\text { - Knowing how to use pictograms and the related } \\
\text { conventions (positioning in a document, } \\
\text { appropriate number, colours, adapted to the local } \\
\text { culture or culturally-neutral) }\end{array}$ \\
\hline
\end{tabular}




\begin{tabular}{|c|c|}
\hline $\begin{array}{l}\text { Intercultural Competence } \\
\text { (the dual perspective - sociolinguistic and textual } \\
\text { - is in the comparison of and contrast between } \\
\text { discursive practices in A, B and C) }\end{array}$ & Intercultural Skills \\
\hline Sociolinguistic Dimension & Sociolinguistic Dimension \\
\hline $\begin{array}{l}\text { - Knowing how to recognise function and } \\
\text { meaning in language variations (social, } \\
\text { geographical, historical, stylistic) } \\
\text { - Knowing how to identify the rules for } \\
\text { interaction relating to a specific community, } \\
\text { including non-verbal elements (useful knowledge } \\
\text { for negotiation) } \\
\text { - Knowing how to produce a register appropriate } \\
\text { to a given situation, for a particular document } \\
\text { (written) or speech (oral) }\end{array}$ & $\begin{array}{l}\text { - Knowing how to recognise function and } \\
\text { meaning in language variations (social, } \\
\text { geographical, historical, stylistic) } \\
\text { - Knowing how to identify the rules for } \\
\text { interaction relating to a specific community, } \\
\text { including non-verbal } \\
\text { elements (useful knowledge for negotiation) } \\
\text { - Knowing how to produce a register appropriate } \\
\text { to a given situation, for a particular document } \\
\text { (written) or speech (oral) }\end{array}$ \\
\hline Textual Dimension & Textual Dimension \\
\hline $\begin{array}{l}\text { - Knowing how to understand and analyse the } \\
\text { macrostructure of a document and its overall } \\
\text { coherence (including where it consists of visual } \\
\text { and sound elements) } \\
\text { - Knowing how to grasp the presuppositions, the } \\
\text { implicit, allusions, stereotypes and inter textual } \\
\text { nature of a document } \\
\text { - Knowing how to describe and evaluate one's } \\
\text { problems with comprehension and define } \\
\text { strategies for resolving those problems } \\
\text { - Knowing how to extract and summarise the } \\
\text { essential information in a document (ability to } \\
\text { summarise) } \\
\text { - Knowing how to recognise and identify } \\
\text { elements, values and references proper to the } \\
\text { cultures represented } \\
\text { - Knowing how to bring together and compare } \\
\text { cultural elements and methods of composition } \\
\text { - Knowing how to compose a document in } \\
\text { accordance with the conventions of the genre and } \\
\text { rhetorical standards } \\
\text { - Knowing how to draft, rephrase, restructure, } \\
\text { condense, and post-edit rapidly and well (in } \\
\text { languages A and B) }\end{array}$ & $\begin{array}{l}\text { - Knowing how to grasp the presuppositions, the } \\
\text { implicit, allusions, stereotypes and inter textual } \\
\text { nature of a document } \\
\text { - Knowing how to describe and evaluate one's } \\
\text { problems with comprehension and define } \\
\text { strategies for resolving those problems } \\
\text { - Knowing how to extract and summarise the } \\
\text { essential information in a document (ability to } \\
\text { summarise) } \\
\text { - Knowing how to recognise and identify } \\
\text { elements, values and references proper to the } \\
\text { cultures represented } \\
\text { - Knowing how to bring together and compare } \\
\text { cultural elements and methods of composition } \\
\text { - Knowing how to compose a document in } \\
\text { accordance with the conventions of the genre and } \\
\text { rhetorical standards } \\
\text { - Knowing how to draft, rephrase, restructure, } \\
\text { condense, and post-edit rapidly and well (in } \\
\text { languages A and B) }\end{array}$ \\
\hline Information Mining Competence & Information Mining Skills \\
\hline $\begin{array}{l}\text { - Knowing how to identify one's information and } \\
\text { documentation requirements } \\
\text { - Developing strategies for documentary and } \\
\text { terminological research (including approaching } \\
\text { experts) } \\
\text { - Knowing how to extract and process relevant } \\
\text { information for a given task (documentary, } \\
\text { terminological, phraseological information) } \\
\text { - Developing criteria for evaluation vis-à-vis } \\
\text { documents accessible on the Internet or any other } \\
\text { medium, i.e., knowing how to evaluate the } \\
\text { reliability of documentary sources (critical mind) } \\
\text { - Knowing how to use tools and search engines } \\
\text { effectively (e.g., terminology software, electronic } \\
\text { corpora, electronic dictionaries) } \\
\text { - Mastering the archiving of one's own documents }\end{array}$ & $\begin{array}{l}\text { - Knowing how to identify one's information and } \\
\text { documentation requirements } \\
\text { - Developing strategies for documentary and } \\
\text { terminological research (including approaching } \\
\text { experts) } \\
\text { - Knowing how to extract and process relevant } \\
\text { information for a given task (documentary, } \\
\text { terminological, phraseological information) } \\
\text { - Developing criteria for evaluation vis-à-vis } \\
\text { documents accessible on the Internet or any other } \\
\text { medium, i.e., knowing how to evaluate the } \\
\text { reliability of documentary sources (critical mind) } \\
\text { - Knowing how to use tools and search engines } \\
\text { effectively (e.g., terminology software, electronic } \\
\text { corpora, electronic dictionaries) } \\
\text { - Mastering the archiving of one's own documents }\end{array}$ \\
\hline
\end{tabular}




\begin{tabular}{|c|c|}
\hline Thematic Competence & Thematic Skills \\
\hline $\begin{array}{l}\text { - Knowing how to search for appropriate } \\
\text { information to gain a better grasp of the thematic } \\
\text { aspects of a document (see Information mining } \\
\text { competence) } \\
\text { - Learning to develop one's knowledge in } \\
\text { specialist fields and applications (mastering } \\
\text { systems of concepts, methods of reasoning, } \\
\text { presentation, controlled language, terminology, } \\
\text { etc.) (learning to learn) } \\
\text { - Developing a spirit of curiosity, analysis and } \\
\text { summary }\end{array}$ & $\begin{array}{l}\text { - Knowing how to search for appropriate } \\
\text { information to gain a better grasp of the thematic } \\
\text { aspects of a document (see Information mining } \\
\text { competence) } \\
\text { - Learning to develop one's knowledge in } \\
\text { specialist fields and applications (mastering } \\
\text { systems of concepts, methods of reasoning, } \\
\text { presentation, controlled language, terminology, } \\
\text { etc.) (learning to learn) } \\
\text { - Developing a spirit of curiosity, analysis and } \\
\text { summary }\end{array}$ \\
\hline Technological Competence (Mastery of Tools) & Technological Skills \\
\hline $\begin{array}{l}\text { - Knowing how to use effectively and rapidly and } \\
\text { to integrate a range of softwares to assist in } \\
\text { correction, translation, terminology, layout, } \\
\text { documentary research (for example text } \\
\text { processing, spell and grammar check, the } \\
\text { Internet, translation memory, terminology } \\
\text { database, voice recognition software) } \\
\text { - Knowing how to create and manage a database } \\
\text { and files } \\
\text { - Knowing how to adapt to and familiarise oneself } \\
\text { with new tools, particularly for the translation of } \\
\text { multimedia and audiovisual material } \\
\text { - Knowing how to prepare and produce a } \\
\text { translation in different formats and for different } \\
\text { technical media } \\
\text { - Knowing the possibilities and limits of MT }\end{array}$ & $\begin{array}{l}\text { - Knowing how to use effectively and rapidly the } \\
\text { standard tools in TW (word processor, desktop } \\
\text { publishing tools, state of the art mark-up } \\
\text { languages (XML, HTML ...) ) } \\
\text { - Knowing how to use effectively and rapidly the } \\
\text { standard tools for creating content for web sites } \\
\text { - Knowing how to use effectively and rapidly the } \\
\text { standard tools for creating content for E-learning } \\
\text { modules } \\
\text { - Knowing how to use effectively and rapidly and } \\
\text { to integrate a range of software to assist editing, } \\
\text { terminology, documentary research (spell and } \\
\text { grammar check, the Internet, translation memory, } \\
\text { terminology database, voice recognition } \\
\text { software...) } \\
\text { - Knowing how to create and manage a database } \\
\text { and files in particular for electronic document } \\
\text { management systems (using, saving, } \\
\text { modifications, adding versions...) } \\
\text { - Knowing how to adapt to new tools in particular } \\
\text { through technological watch } \\
\text { - Knowing how to adapt technical documents to } \\
\text { various media }\end{array}$ \\
\hline
\end{tabular}

